\title{
Model Pembelajaran Creative Problem Solving pada Kemampuan Berpikir Kreatif dan Hasil Belajar Tematik Siswa Sekolah Dasar
}

\author{
Resti Ajeng Pramestika ${ }^{1}$, Heri Suwignyo ${ }^{2}$, Sugeng Utaya $^{3}$ \\ ${ }^{1}$ Pendidikan Dasar-Universitas Negeri Malang \\ ${ }^{2}$ Pendidikan Bahasa Indonesia-Universitas Negeri Malang \\ ${ }^{3}$ Pendidikan Geografi-Universitas Negeri Malang
}

\begin{tabular}{l}
\hline \hline INFO ARTIKEL \\
\hline Riwayat Artikel: \\
Diterima: 02-08-2019 \\
Disetujui: 16-03-2020 \\
\hline
\end{tabular}

\section{Kata kunci:}

learning model; creative problem solving, creative thinking skills; learning outcomes; model pembelajaran; creative problem solving; kemampuan berpikir kreatif; hasil belajar

\begin{abstract}
ABSTRAK
Abstract: The purpose of this study is describe the differences a creative thinking skills and thematic learning outcomes learned using CPS learning model in the experiment class and students learned with conventional models in the control class. This research using a quasi experimental design with a non-equivalent control group design using the pretest-posttest score test and creative thinking ability questionnaire. Research data was obtained through tests. The results a research show that (1) there was a significan influences a CrPS learning model on students 'creative thinking abilities, (2) there was the influence of the CPS learning model on students' thematic learning outcomes.

Abstrak: Tujuan penelian ini yaitu untuk mendeskripsikan perbedaan antara kemampuan berpikir kreatif dan hasil belajar tematik yang diterapkan dengan model pembelajaran CrPS di kelas eksperimen serta siswa yang diterapkan dengan model konvensional di kelas kontrol. Penelitian ini menggunakan design quasi eksperimen dengan rancangan nonequivalent control group dengan menggunakan nilai tes pretest-posttest. Data penelitian diperoleh melalui tes dan angket kemampuan berpikir kreatif. Penelitian menunjukkan hasil (1) terdapat pengaruh yang signifikan model pembelajaran CPS terhadap kemampuan berpikir kreatif siswa, (2) terdapat pengaruh model pembelajaran CPS terhadap hasil belajar tematik siswa.
\end{abstract}

\author{
Alamat Korespondensi: \\ Resti Ajeng Pramestika \\ Pendidikan Dasar \\ Universitas Negeri Malang \\ Jalan Semarang 5 Malang \\ E-mail: pramestika.resti@gmail.com
}

Kreativitas adalah suatu komponen yang perlu ditingkatkan untuk dapat bersaing dan memenuhi tuntutan dari perkembangan zaman. Guru harus mampu menggiring siswa agar menjadi pribadi kreatif dan mengaktifkan potensi kreatif yang dimiliki oleh masing-masing siswa. Pada dasarnya, tidak semua siswa terbiasa berhadapan dengan permasalahan sehingga menjadikan diri siswa menjadi pribadi yang kreatif. Pergeseran paradigma LOTS (low order thingking skills) ke HOTS (high order thingking skills) juga membutuhkan inovasi model-model pembelajaran yang memuat keterampilan mengembangkan kreativitas dengan peran guru yang memiliki kemampuan mengajar yang profesional. Proses pembelajaran di sekolah berpengaruh terhadap pola berpikir siswa. Pembelajaran berpusat pada guru menjadi salah faktor yang memengaruhi pola berpikir kreatif siswa. Proses pembelajaran tersebut menjadikan siswa tidak dapat mengembangkan berpikir kreatif dengan mencari berbagai informasi sebagai sumber belajar. Konsisten dengan kepribadian dan pengetahuan yang dimilikinya menjadi faktor yang penting dalam mengembangkan kreativitasnya (Se'bastien He'lie, 2010). Kurangnya pembelajaran berbasis pemecahan masalah yang diberikan kepada siswa juga memengaruhi berpikir kreatif yang dimilikinya.

Berpikir kreatif diperlukan untuk meningkatkan kualitas hidup, untuk itu kemampuan berpikir kreatif perlu untuk dikembangkan. Munandar (2009) menjelaskan bahwa perlunya mengembangkan kreativitas dikarenakan, yaitu (1) seseorang yang mampu berkreasi sehingga mewujudkan dirinya, hal tersebut merupakan kebutuhan penting dalam hidup manusia, (2) penyelesaian terhadap suatu masalah dapat terselesaikan dengan adanya bermacam-macam kemungkinan alternatif sebagai perwujudan kreativitas, (3) kreativitas yang diimbangi dengan menyibukkan diri dapat memberikan kepuasan terhadap individu, (4) kualitas hidup seorang dapat meningkat salah satunya dengan kreativitas. Kreativitas pada saat ini dapat diimplementasikan guru pada kurikulum 2013, dimana pembelajaran ini menggunakan dasar pendekatan scientific. Pembelajaran tematik yang menggunakan pendekatan scientific disarankan memakai model pembelajaran berbasis membangun cara pikir siswa dan mampu mengembangkan dan menunjukkan keterampilan berpikir dan bertindak kreatif, produktif, kritis, mandiri, kolaboratif, dan komunikatif. Melalui pemikiran kreatif, semua potensi diri berharga dapat lahir terutama dalam hal menuangkan ide secara 
imajinatif, menyimpang, dan lateral (Syahrin, dkk. 2019). Menurut Nurul Akmal (2018), pembelajaran dengan model CrPS memberi efek yang baik dalam pengembangan kegiatan belajar karena relevan dengan kehidupan siswa. Model ini dapat dilakukan melalui enam langkah atau tahap yang telah dijabarkan, yaitu (1) menemukan tujuan, (2) menemukan fakta, (3) mampu memecahkan masalah, (4) menemukan gagasan, (5) menemukan solusi, dan (6) penerimaan. Adanya enam tahapan dalam model ini menjelaskan langkah sistematis saat mengidentifikasi tantangan, menciptakan gagasan dan menerapkan penyelesaian yang beragam. Pada kegiatan observasi awal yang dilakukan peneliti di SDN Bandungrejosari 3 Kota Malang pada tanggal 5-9 November 2018 dengan seorang guru kelas V, guru tersebut menyampaikan bahwa ada beberapa siswa-siswi kesulitan dalam memecahkan masalah dan memahami materi karena terkendala dengan berubah kurikulum.

Peningkatan kualitas pembelajaran memang diperlukan dalam mengajar. Usaha untuk mengatasi permasalahan di atas seperti kesulitan dalam memecahkan masalah serta nilai yang masih kurang memenuhi KKM dengan cara meningkatkan pengetahuan siswa dengan diajarkannya melalui proses pembelajaran dan pemberian model pembelajaran yang variatif agar siswa dapat berkreasi dan tidak bosan dalam proses memecahkan masalah maupun memahami materi. Implementasi pembelajaran dengan memakai pengalaman siswa secara langsung mampu membantu siswa menemukan konsep yang dibahas dalam kegiatan di kelas (Rumidani, 2014). Menurut Abdul Kadir (2015) pembelajaran tematik disusun dengan tujuan untuk meningkatkan hasil belajar yang optimal dengan pengalaman siswa yang memiliki macam pandangan dari aspek kehidupan. Selain berguna melatih siswa guna berpikir secara kreatif dalam memecahkan masalah serta dapat meningkatkan interaksi dan aktivitas siswa agar bisa saling mendukung dalam penguasaan materi pembelajaran yang berdampak pada hasil belajar. Pembelajaran tematik yang dirasa masih membingungkan karena terdapat berbagai mata pelajaran didalamnya yang digabung menjadi satu dirasa masih perlu tinjauan yang lebih khusus oleh pendidik, diterapkannya model pembelajaran ini diharapkan kesulitan yang dihadapi siswa dalam pembelajaran Kurikulum 2013, yakni pembelajaran tematik dapat diatasi dengan cara berpikir kreatif sehingga hasil belajarnya pun akan meningkat. Pembelajaran tematik ini akan efektif ketika mencakup sebagian besar standar pelaksanaan yang baik yang tercermin dari proses pelaksanaan dengan menerapkan seluruh indikator yaitu context,input, process, dan product. (Muhammad Abduh, dkk., 2014)

Penelitian yang pernah diterapkan terhadap penggunaan model pembelajaran CrPS di antaranya adalah penelitian yang pernah dilakukan oleh Akmil Fuadi Rahman (2015) mengungkapkan bahwa ada pengaruh positif pada kompetensi pemecahan masalah siswa menggunakan model CrPS yang dilakukan pada siswa kelas VII SMPN 1 Banjarmasin bahwa aktivitas selama proses belajar dengan CrPS berada pada kriteria baik dan kompetensi berpikir kreatif di kelas eksperimen berbada daripada kemahiran berpikir kreatif pada siswa kelas kontrol dengan menggunakan model PBL. Penelitian lain oleh Setiawan (2016) pada siswa kelas XI MAN 3 Kota Malang juga menunjukan bahwa efektivitas berpikir kreatif siswa mengalami peningkatan setelah menerapkan model pembelajaran CrPS berkolaborasi teknik sinektik. Pengetahuan siswa dalam menyelesaikan permasalahan tersebut membuat proses belajar bermakna dan dapat dijadikan sebagai modal guna menjalani kehidupan sehari-hari.

Model pembelajaran CrPS membantu guru mengaitkan antar tema yang akan diajarkan, guna menghadapi dan menyiapkan guru maupun siswa di era revolusi industri 4.0. Menurut Oktaviani (2015) pembelajaran CrPs membelajarkan siswa guna mengembangkan sistem berpikir kreatif dalam menyelesaikan masalah dengan cara yang sistematis dan terarah, hal ini menjadikan siswa bisa mencerna konsep materi yang ada dan bisa menyampaikan pendapatnya dengan baik. Guna menyiapkan peserta didik yang siap di era revolusi industri 4.0 terdapat 3 karakter utama generasi millenial yaitu (1) creative, cenderung berpikir luas yang merupakan bukti bahwa tumbuhnya industri start up dan industri beragam lainnya yang dimonitori anak muda, (2) confidence, yaitu sangat percaya diri dengan berani menyatakan pendapatnya, bahkan berdebat pada laman social media, (3) connected, dimana remaja pandai bertukar informasi dan kemampuan yang dilihat dari kefasihan mereka di banyak media sosial. Tujuan penelitian ini yaitu, (1) mengetahui adanya pengaruh model pembelajaran CrPS terhadap kemampuan berpikir kreatif siswa, (2) mengetahui pengaruh model pembelajaran CrPS terhadap hasil belajar tematik siswa kelas V di SDN Bandungrejosari 3 Malang. Hipotesis dalam penelitian ini, yaitu (1) terdapat pengaruh model pembelajaran pemecahan masalah kreatif pada kompetensi berpikir kreatif siswa, (2) terdapat pengaruh model pembelajaran pemecahan masalah kreatif pada hasil belajar tematik siswa.

\section{METODE}

Desain dalam penelitian ini menggunakan desain nonequivalent control group design. Penelitian ini merupakan eksperimen. Adapun rancangan di penelitian ini adalah eksperimen semu atau sering disebut quasi experiment. Eksperimen semu yaitu peneliti menggunakan kelompok kontrol dan kelompok eksperimen. Penelitian ini diterpkan di SDN Bandungrejosari 3 Malang, subjek penelitian meliputi siswa kelas V yang terdapat dari dua kelas, yaitu kelas A dan B yang bertindak sebagai kelas yang menggunakan model CrPs atau disebut dengan kelas eksperimen dan kelas V-A bertindak sebagai kontrol dengan masingmasing terdiri dari 30 pada kelas V-A dan 26 siswa pada kelas V-B. Variabel pada penelitian ini, yaitu (1) model pembelajaran CrPS sebagai variabel independent, (2) kemampuan berpikir kreatif siswa sebagai variabel dependen, dan (3) hasil belajar juga sebagai variabel dependen. Dari hasil dari belajar pada instrumen melalui nilai pretest-posttest, sedangkan untuk mengukur kemampuan berpikir kreatif dan hasil belajar diberikan tes yang berupa soal pilihan ganda, serta angket guna menentukan kompetensi berpikir kreatif siswa berupa pernyataan. 
Teknik dalam penelitian ini menggunakan pengumpulan data, yaitu (1) test berpikir kreatif yang diukur dengan pre-test dan post-test, berupa gain score, (2) dokumentasi digunakan guna mendapatkan data penunjang yang besifat sekunder, seperti surat perijinan, foto kegiatan pembelajaran, dan (3) observasi dilakukan untuk mengamati ketika proses pembelajaran berlangsung yaitu terkait dengan penerapan model pembelajaran Analisis uji prasyarat pada penelitian yaitu uji normalitas memakai kolmogorov - smirnov dengan program statistik dan uji homogenitas memakai Leven's test (one-way anova). Pada uji hipotesis dilakukan melalui uji - $\mathrm{t}$ dengan bantuan statistik.

\section{HASIL}

Hasil pengolahan data pada kompetensi berpikir kreatif siswa diperoleh menggunakan angket dengan diberikannya perlakuan pada kelas V-A bertindak sebagai kelas eksperimen dan kelas V-B sebagai kelas dengan model pembelajaran konvensional yaitu kelas kontrol. Rata-rata nilai siswa dijelaskan pada tabel 1.

Tabel I. Perbedaan Hasil Kemampuan Berpikir Kreatif pada Kelas Eksperimen dan Kelas Kontrol

\begin{tabular}{lcccc}
\hline & Jumlah Siswa & Minimal & Maksimal & Rata-rata Nilai \\
\hline Eksperiment (V-A) & 30 & 76 & 91 & 81,5 \\
Kontrol (V-B) & 26 & 60 & 91 & 71 \\
\hline
\end{tabular}

Dari tabel tersebut dapat dijelaskan hasil nilai minimal pad akelas V-A sebagai kelas eksperimen memperoleh nilai 76 dan V-B yaitu sebagai kelas kontrol memperoleh nilai 60, sedangkan nilai maksimum kelas eksperimen dengan model CrPS yaitu sama-sama dengan kelas kontrol yaitu pada nilai 91. Sementara itu, pada rata-rata nilai pada kelas V-A yaitu 81,5 dan kelas V-B sebesar 71. Dengan hasil ini dapat dijelaskan bahwa ada perbedaan kemampuan berpikir kreatif sebagai akibat dari diberikannya perlakuan yang berbeda saat pembelajaran. Perbedaan pada kompetensi berpikir kreatif siswa dijelaskan diagram pada gambar 1 .

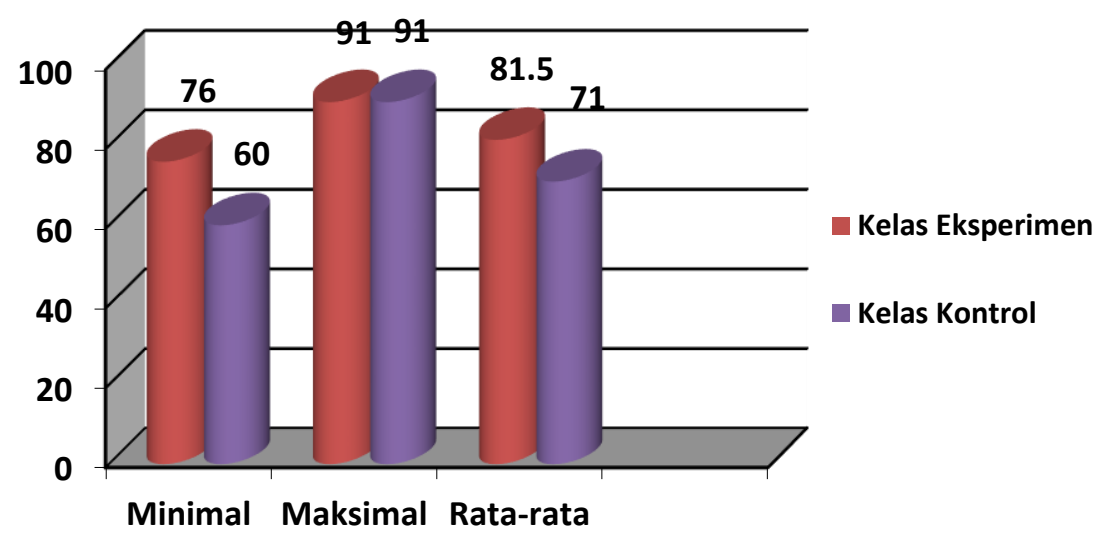

\section{Gambar 1. Diagram Perbedaan Kemampuan Berpikir Kreatif Siswa}

Pada hasil pembelajaran di kedua kelas setelah diterapkannya model yang berbeda mengalami perbedaan. Guna melihat skor dalam perlakuan penelitiannya yang dilakukan di kedua kelas yang berbeda, maka hasil perhitungan rata-rata pretest-posttest di kedua kelas tersebut dibuat pada tabel 2.

Tabel 2. Perbedaan Hasil Pembelajaran

\begin{tabular}{lcc}
\hline \multirow{2}{*}{ Jenis Test } & \multicolumn{2}{c}{ Kelas } \\
\cline { 2 - 3 } & Eksperiment (V-A) & Kontrol (V-B) \\
\hline Pretest & 66.33 & 65.16 \\
Posttest & 83.66 & 74.83 \\
Selisih & 17.33 & 9.66 \\
\hline
\end{tabular}

Hasil yang dapat dijelaskan dari tabel II yaitu dapat diketahui bahwa rata-rata pre-test kelasV-A sebagai kelas eksperimen sebesar 66.33 dan V-B yaitu berada pada kelas kontrol 65.16. Sementara itu, rata-rata nilai yang didapatkan pada hasil posttest guna mengukur hasil belajar siswa kelas V-A dengan jumlah siswa 30 yaitu mendapat nilai 83.66, sedangkan pada kelas V-B dengan jumlah siswa 26 yaitu pada nilai 74.83. Dari perhitungan nilai rata-rata pret-est serta post-test maka selisis dari kedua kelas yaitu 17.33, untuk kelas V-A dan 9.66 yang didapati untuk kelas V-B. Perbedaan rata-rata nilai pre-test dan post-test dijelaskan pada diagram gambar 2 . 


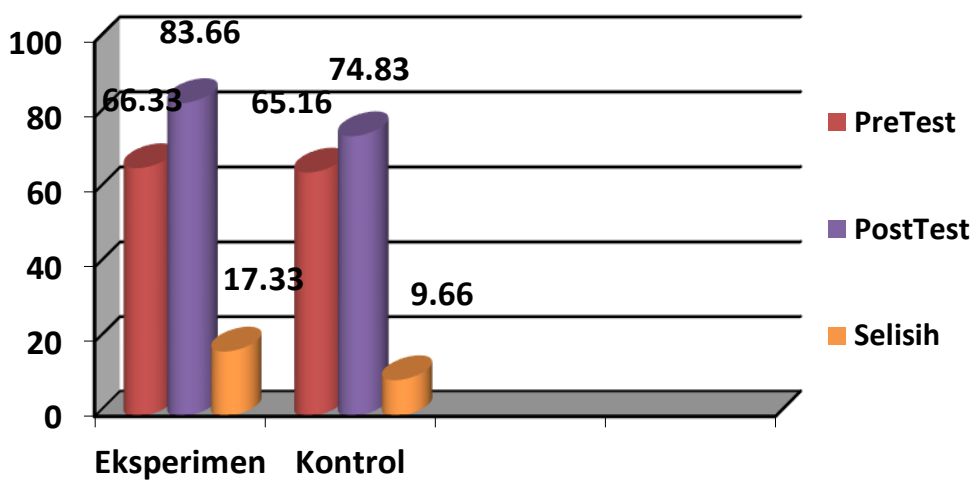

\section{Gambar 2. Diagram Perbedaan Nilai Hasil Belajar Siswa Kelas Eksperimen dan Kelas Kontrol}

Hasil uji prasyarat yang diujikan dengan menggunakan uji normalitas kompetensi berpikir kreatif serta hasil belajar menunjukkan data yang terdistribusi normal. Hasil data kemampuan berpikir kreatif diperoleh signifkansi 0,101 dan 0,1335 . Untuk hasil belajar menunjukkan nilai signifikan 0,069>0,05 dan nilai signifikan $0,055>0,05$, maka hasil belajar terdistribusi normal. Uji homogenitas pada kompetensi berpikir kreatif dapat diketahui bahwa kompetensi berpikir kreatif berada pada taraf sigifikan sebesar 0,823 artinya data tersebut homogen. Simpulannya bahwa nilai kelas V-A dan kelas V-B memiliki varians yang sama atau nilai yang bersifat homogen.

Pada uji selanjutnya yaitu dilakukannya uji prasyarat, tahap selanjutnya yaitu analisis data dengan uji hipotesis pada model pembelajaran CrPS terhadap penguasaan cara berpikir kreatif dan hasil belajar tematik siswa. Pengujian pada hipotesis di penelitian ini menggunakan uji-t , hasilnya dapat dijelaskan sebagai berikut. Pertama, Hasil Uji Hipotesis Pengaruh Model CPS Terhadap Hasil Belajar Siswa. Hasil analisis data dijelaskan bahwa nilai signifikansi (2-tailed) = 0,000 $<0,05$ sehingga dapat dijelaskan pada simpulan bahwa pada kelas eksperimen ini Ho nya ditolak dan Ha nya diterima. Pada proses uji hasil belajar melalui uji hipotesis ini menunjukkan hasil perhitungan sebesar 4,995, sedangkan t-tabel dengan jumlah subjek penelitian ( $\mathrm{N}=60$ ) adalah sebesar 2,00030, maka 4,995 > 2,00030. Dari hal tersebut dapat ditarik kesimpulan terdapat pengaruh yang signifikan model pembelajaran CrPS terhadap hasil belajar. Kedua, Hasil Uji Hipotesis Pengaruh Model CPS Terhadap Kemampuan Berpikir Kreatif. Hasil analisis data dideskripsikan bahwa nilai signifikansi (2-tailed) =0,038<0,05, pada nilai signifikansi tersebut dapat ditarik simpulan bahwa pada kelas eksperimen ini Ho nya ditolak dan Ha nya diterima. Efektivitas berpikir kreatif melalui uji hipotesis ini mendapatkan hasil perhitungan sebesar 2,123, sedangkan pada perhitungan table-t atau $t$-table dengan jumlah subjek penelitian $(\mathrm{N}=60)$ adalah sebesar 2,00030, maka 2,123 > 2,00030. Dari hal tersebut dapat ditarik kesimpulan bahwa model pembelajaran CrPS dapat memengaruhi kompetensi berpikir kreatif siswa.

\section{PEMBAHASAN}

\section{Model Pembelajaran CrPS Pada Kemampuan Berpikir Kreatif}

Hasil perhitungan pada statistik menunjukkan bahwa model pembelajaran CrPS berpengaruh pada hasil kompetensi berpikir kreatif. Pada penjelasan di analisis uji data menunjukkan bahwa terdapat perbedaan antara tingkat efektivitas berpikir kreatif antara kedua kelas. Hal ini dapat dilihat dan dijelaskan dengan terdapatnya perbedaan gain score atau kenaikan nilai antara kelas V-A dan V-B sebagai subjek penelitian ini. Selain itu, rata-rata skor efektivitas berpikir kreatif kelas eksperimen lebih tinggi daripada skor kelas kontrol. Hasil analisis ini juga terbukti dengan kompetensi berpikir kreatif ini siswa mampu berkembang dari jenis kategori sedang menjadi kategori yang lebih baik. Pengaruh kuat pembelajaran CrPS dalam peningkatan kompetensi berpikir kreatif siswa akan terlihat jika terdapat ciri-ciri diantaranya, (1) siswa terlibat lebih aktif dalam proses belajar mengajar di dalam kelas, (2) siswa mempu mengembangkan cara berpikir mandiri dan berimajinasi sesuai dengan materi yang diberikan guru, (3) kondisi di kelas yang tenang dan waktu belajar yang cukup mendukung guna proses penyampaian materi, (4) proses bekerjasama dan berkolaborasi dalam memecahkan permasalahan berupa penyelidikan masalah secara mendalam yang ditunjukkan antar peserta, (5) siswa bisa menerima gagasan dari teman kelompoknya, dan (6) siswa tidak mem-bully gagasan temannya dari kerjasama kelompoknya (Triyono, 2017).

Pada model bentuk CrPS ini sangat sesuai diterapkan pada kompetensi berpikir kreatif siswa karena pada setiap akhir pembelajaran siswa diberikan kesempatan secara mandiri untuk melakukan evaluasi mendalam, dengan demikian salah satu aspek berpikir kreatif ditekankan pada model pembelajaran CrPS. Terdapatnya berbagai cara yang baru serta pendekatan proses belajar yang baru di dalam ruang kelas pada kompetensi berpikir kreatif, maka perlu dipupuk dan dioptimalkan kembali potensi yang ada pada siswa di dalam kelas guna didapatkannya hasil yang maksimal (Ikromi, 2018). 
Model pembelajaran CrPS ini juga berguna untuk memotivasi, mendorong dan mengoptimalkan perkembagan pengetahuan satu sama lain siswa, dan untuk menguasai keterampilan-keterampilan yang disampaikan dari pendidik. Sehingga siswa lebih bebas atau leluasa untuk bepikir, merespons dan saling membantu. Pada pembelajaran ini guru meminta siswa untuk berdiskusi tentang materi yang diberikan oleh guru tersebut dan siswa bersama anggota kelompoknya saling berdiskusi bertukar ide masing-masing. Menurut pengamatan peneliti, selama proses pembelajaran berlangsung, siswa kelas V-A terlihat semangat, paham dan tenang dalam mengikuti kegiatan di dalam kelas. Siswa juga merasa senang belajar dengan diterapkannya model CPS. Namun, ternyata nilai dari kompetensi berpikir kreatif belajar yang dilihat dari skor angket dan kemudian diolah menjadi ratarata bahwa kemampuan belajar kreatif tidak jauh berbeda dengan siswa kelas V-B. Menurut peneliti, perihal dengan kejadian ini disebabkan oleh berbagai factor sebagai salah satunya yaitu karena siswa kekurang pahaman atau keseriusan dalam proses mambaca maupun mengisi angket. Selain itu, disebabkan oleh minoritas siswa juga terlihat saling menyontek ketika proses isi angket sehingga nilai yang didapat hampir sama.

\section{Pengaruh Model Pembelajaran CPS terhadap Hasil Belajar Siswa}

Hasil dari belajar siswa, baik kelas penerapan model maupun kelas model konvensional diperoleh hasil post-test terdiri dari berbagai soal yang berkaitan sesuai dengan materi tema yang ada. Soal yang diberikan kepada siswa berfungsi sebagai suatu alat untuk mengukur terdapat nilai karakter yang harus disematkan dalam kegiatan dalam kelas maupun tiap tema yang akan disampaikan oleh pemahaman siswa mengenai materi yang telah diajarkan. Hasil belajar yang dipakai pada penelitian ini dari hasil test tulis yang diberikan pada akhir setelah proses pembelajaran atau disebut dengan post-test. Kurikulum 2013 yang saat ini digunakan adalah pembelajaran tematik yang didalamnya guru (Henry Januar, 2014). Bertolak berdasar hasil penelitian diperoleh nilai dari pengolahan data hasil pembelajaran yang menunjukkan bahwa rata-rata skor hasil belajar siswa kelas $\mathrm{V}$-A sebesar 83,66, sedangkan rata-rata skor hasil siswa kelas V-B sebesar 74,83. Apabila dijelaskan pada skor rata-rata antara dua kelompok tersebut dapat diperoleh simpulan jika terdapat perbedaan nilai hasil pembelajaran pada kelas V-A yang menggunakan model CrPS dengan kelas V-B yang menggunakan model pembelajaran yang digunakan guru sehari-hari. Data pada hasil perhitungan ini mendeskripsikan jika penggunaan model CrPS mampu memengaruhi nilai skor siswa di dalam kelas sehingga dapat dijelaskan bahwa model pembelajaran CrPS berpengaruh pada kompetensi berpikir kreatif siswa dan mempunyai dampak baik dalam meningkatkan hasil belajar siswa.

Perencanaan proses pembelajaran di ruang kelas, pelaksanaan dengan baik dan sistematis seuai dengan sintaks belajar, pengamatan materi yang disampaikan dan refleksi atau mengulang kembali materi diyakini bisa meningkatkan hasil belajar secara signifikan (Utami, 2015). Dari proses hasil belajar yang diperoleh melalui kegiatan peneliti di kedua kelas yakni kelas V-A dan kelas V-B, penulis memiliki catatan jika pembelajaran tematik mampu mengatasi beberapa masalah belajar siswa di dalam kelas. Pada model CrPS siswa diberikan kesempatan untuk menuangkan pendapatnya di dalam kelompoknya karena keberhasilan kelompok dilihat dari hasil kerjasama pada tugas yang diberikan. Apabila nilai kelompok itu masih dibawah rata-rata maka guru memberikan tes individual untuk membantu nilai kelompok yang rendah.

Dengan memaksimalkan keaktifan seorang pembelajar dalam proses belajarnya setiap hari dapat dirancang dan dilakukan dengan baik sesuai dengan sintaks perkembangan usia dan pemahaman siswa maka permasalahan dalam belajar yang dialami siswa dapat teratasi serta dapat menumbuhkan kemampuan berpikir kreatif. Munculnya berbagai kemampuan berpikir kreatif sesuai dengan perkembangan zaman dan lingkungan yang berpengaruh dalam diri siswa maka dapat meningkatkan hasil belajar siswa nantinya. Hasil penelitian yang dilakukan menunjukkan bahwa kemampuan berpikir kreatif dan hasil belajar siswa yang diterapkan dengan CrPS lebih baik dibandingkan dengan pembelajar yang menggunakan model konvensional. Hal ini sesuai dengan tanggapan sebagian besar siswa yang mengungkapkan bahwa senang mempelajari materi dengan model pembelajaran yang bervariasi seperti diterapkannya model pembelajaran CrPS sehingga membuat siswa lebih mudah memahami materi yang nantinya akan meningkatkan kreativitas dan hasil belajar.

\section{SIMPULAN}

Model belajar CrPS berpengaruh terhadap kompetensi pikir kreatif dalam diri siswa karena dalam kegiatannya selalu memberikan kebebasan kepada pembelajar guna memunculkan ide atau gagasan pada tiap tahapannya. Terdapatnya pengaruh dan perbedaan model pembelajaran CrPS terhadap kemampuan pikir kreatif siswa di kelas V-A Sekolah Dasar. Hal ini dibuktikan bahwa nilai $\mathrm{t}_{\text {hitung }}>\mathrm{t}_{\text {tabel }}$ yaitu 2,123 $>2,00030$ dari $\mathrm{db}=60$ pada taraf signikansi 5\%. Jadi, dapat disimpulkan bahwa model pembelajaran CrPS berpengaruh terhadap efektivitas berpikir kreatif.

Selain itu, model belajar CrPS ini juga berpengaruh signifikan dengan penggunaan model pembelajaran CrPS terhadap hasil belajar pada siswa kelas V-A sebagai kelas eksperimen, kelas ini diberi materi dan sintaks pembelajaran secara sistematis dan terstruktur sesuai dengan sintaks model pembelajaran CrPS. Pada proses ini dibuktikan dengan didapatkannya gain score yang terdapat pada kelas eksperimen lebih tinggi daripada kelas kontrol dengan hasil perhitungan $t_{\text {hitung }}>\mathrm{t}_{\text {tabel }}$ yaitu $2,123>2$, 00030 dari $\mathrm{db}=60$ pada taraf signikansi 5\%. Dengan demikian, dalam penelitian ini dapat disimpulkan bahwa model pembelajaran $\mathrm{CrPS}$ berpengaruh terhadap hasil pembelajaran di ruang kelas. 
Berdasarkan dari proses temuan yang sudah dibahas, disini peneliti merumuskan saran, yaitu (1) kepada pendidik pada jenjang SD disarankan menerapkan model pembelajaran CrPS yang mampu menstimulus secara sistematis pembelajaran dengan baik, sehingga tujuan dan hasil dari proses implementasi pembelajaran dapat tercapai. Khususnya pemilihan model ini mampu meningkatkan kompetensi proses pikir kreatif dan hasil belajar kreatif pembelajar, (2) kepada sekolah adalah dapat digunakan sebagai peningkatan mutu pendidikan dan hasil belajar siswa dengan menerapkan model CrPS dalam pembelajaran yang berlangsung di dalam kelas, dan (3) bagi peneliti selanjutnya, sebagai acuan guna penerapan dan uji model belajar model CrPS dalam kelas guna memperbaiki kekurangan yang dilakukan peneliti sekarang.

\section{DAFTAR RUJUKAN}

Abduh, M., Nugroho., \& Siskandar. (2014). Evaluasi Pembelajaran Tematik Dilihat dari Hasil Belajar Siswa. Indonesian Journal of Curriculum and Educational Technology Studies, 1(1), 1—9.

Akmal, N., \& Saputra, E. (2018). Penerapan Pendekatan Creative Problem Solving untuk Meningkatkan Kemampuan Koneksi Matematis Siswa. Symmetry| Pasundan Journal of Research in Mathematics Learning and Education, 3(2), $137-144$.

Hélie, S., \& Sun, R. (2010). Incubation, Insight, and Creative Problem Solving: A Unified Theory and a Connectionist Model. In Psychological Review, 117(3), 994-1024. https://doi.org/10.1037/a0019532

Ikromi, S. L. (2018). Meningkatkan Kemampuan Berpikir Kreatif Matematis Siswa SMA melalui Pembelajaran Open-Ended pada Materi SPLTV. Jurnal Matematika Statistika dan Komputasi, 15(2), 104. https://doi.org/10.20956/jmsk.v15i2.5719

Lisliana, Agung Hartoyo, B. (2016). Analisis Kemampuan Berpikir Kreatif Siswa Dalam Menyelesaikan Masalah pada Materi Segitiga di SMP. Jurnal Pendidikan dan Pembelajaran Untan Pontianak, 5(11), 1-11.

Munandar, U. (2009). Pengembangan Kreativitas Anak Berbakat. Jakarta: Rineka Cipta.

Oktaviani, A. N., \& Nugroho, S. E. (2015). Penerapan Model Creative Problem Solving pada Pembelajaran Kalor untuk Meningkatkan Pemahaman Konsep dan Keterampilan Komunikasi. Unnes Physics Education Journal, 4(1), 26 - 31. https://doi.org/10.15294/upej.v4i1.4733

Rahman, A. F., \& Maslianti. (2015). Pengaruh Model Creative Problem Solving (CPS) Dalam Pembelajaran Matematika terhadap Kemampuan Berpikir Kreatif pada Siswa Sekolah Menengah Pertama. Jurnal Pendidikan Matematika, 3(1), $67-74$.

Rumidani, N. M., Marhaeni, A. A. I. N., Tika, I. N. (2014). Implementasi Pembelajaran Tematik Berbasis Lingkungan untuk Meningkatkan Motivasi dan Hasil Belajar Calistung Siswa Sekolah Dasar. Jurnal Pendidikan Dasar Ganesha, (Vol. 4)

Saputra, H. J., Novitasari A. D. (2014). Keefektifan Pembelajaran Outdoor Learning Berbasis Nilai Karakter terhadap Hasil Belajar Tematik Terintegrasi Siswa Kelas IV SD Negeri 1 Meteseh Rembang. Jurnal Kependidikan, 4(2), 26-34

Syahrin, A., Suwignyo, H., \& Priyatni, E. T. (2019). Creative Thinking Patterns in Student's Scientific Works. Eurasian Journal of Educational Research, 19(81), 1-16. https://doi.org/10.14689/ejer.2019.81.2

Sudarma, M. (2016). Mengembangkan Keterampilan Berpikir Kreatif. Jakarta: PT Raja Grafindo Persada.

Triyono., Senam., Junaedi., \& Wilujeng, I. (2017). Pengaruh Pembelajaran IPS Berbasis Creative Problem Solving terhadap Kreativitas Siswa SMP. Jurnal Kependidikan, 1(2), 214-226.

Utami, S. E. (2015). Penerapan Strategi Pembelajaran Tematik untuk Meningkatkan Kreativitas dan Hasil Belajar Siswa. Jurnal Paradigma, 2(1), 206-218. 